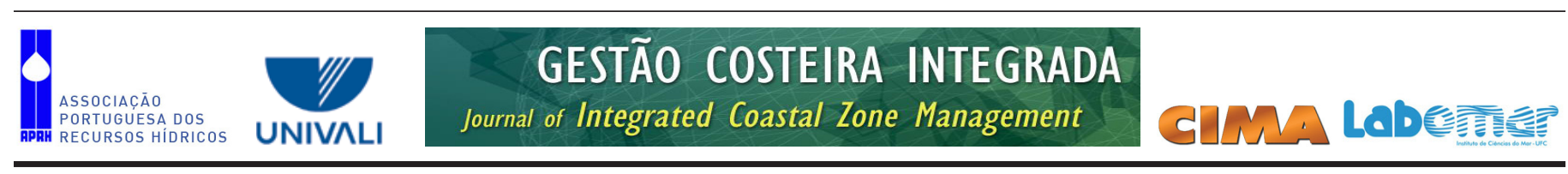

http://www.aprh.pt/rgci/pdf/rgci-371_Carvalho.pdf | DOI:10.5894/rgci371

\title{
Factors affecting the distribution of epibenthic biodiversity in the Cávado estuary (NW Portugal) *
}

\section{Fatores que afetam a distribuição da biodiversidade epibentónica do estuário do Cávado (NW Portugal)}

\author{
A. N. Carvalho ${ }^{\circledR, 1}$, P. T. Santos ${ }^{1}$
}

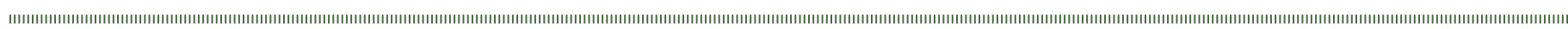

\begin{abstract}
The epibenthic fauna of the lower Cávado estuary at five sampling stations was studied over a period of two years. We examined the spatial and seasonal distribution of different species and analysed temperature, salinity, dissolved oxygen, precipitation and sediment type, which are all important features of estuarine dynamics. A total of 15 taxa were identified. Crustaceans had the highest levels of abundance (91\%) and biomass (87\%). Crangon crangon was the most abundant species (75\%) and Carcinus maenas had the highest biomass (71\%). No exotic species were recorded. Multivariate analysis showed two different spatial assemblages, one corresponding to stations nearest to the mouth (higher abundance values) and other to the upstream stations. The Shannon diversity index was highest at the margin station further upstream. Three different assemblages could be distinguished, separating summer/autumn (higher values of abundance) from spring and from winter.

According to BIOENV analysis, dissolved oxygen, water temperature and salinity were the environmental variables responsible for the spatial and seasonal distribution of epibenthos, explaining 17.2\% of variability. Abundance and biomass were better correlated with water temperature. Sediment type was also important in epibenthic spatial distribution, being abundance, biomass and diversity indexes better correlated with fine sediment $(<0.125 \mathrm{~mm})$.
\end{abstract}

Keywords: epibenthos; estuarine ecosystem; diversity; environmental variables

\section{RESUMO}

A fauna epibentónica do estuário inferior do Rio Cávado foi estudada em cinco estaçóes de amostragem durante um período de dois anos. Apresentamos a distribuição espacial e sazonal das diferentes espécies e uma análise da temperatura, salinidade, oxigénio dissolvido, precipitação e tipo de sedimento, sendo todas, importantes características da dinâmica estuarina. Foram identificados um total de 15 taxa. Os crustáceos apresentaram os valores mais elevados de abundância (91\%) e biomassa (87\%). Crangon crangon foi a espécie mais abundante (75\%) e Carcinus maenas apresentou o valor de biomassa mais elevado (71\%). Nenhuma espécie exótica foi registada neste estuário. Análise multivariada mostrou dois grupos espaciais diferentes, um correspondendo às estaçôes de amostragem mais próximas da boca do estuário (valores mais elevados de abundância) e outro às estaçóes de montante. O valor do indice de diversidade de Shannon foi mais elevado a montante na estação localizada na margem. Três grupos diferentes podem ser distinguidos, separando o verãoloutono (valores elevados de abundância) da primavera e do inverno.

@- Corresponding author ancarvalho@gmail.com

1 - Universidade do Porto, Faculdade de Ciências, Rua Campo Alegre s/n, 4169-007 Porto, Portugal / CIIMAR - Centro Interdisciplinar de Investigação Marinha e Ambiental, Rua dos Bragas 289, 4050-123 Porto, Portugal 
Segundo a análise BIOENV, o oxigénio dissolvido, a temperatura e a salinidade da água, foram as variáveis ambientais responsáveis pela distribuiçâo espacial e sazonal dos epibentos, explicando $17.2 \%$ da variabilidade. A abundância e a biomassa estiveram melhor correlacionadas com a temperatura. O tipo de sedimento também foi importante na distribuiçáo espacial dos epibentos, sendo que a abundância, biomassa e indices de diversidade estiveram melhor correlacionados com o sedimento fino $(<0.125 \mathrm{~mm})$.

Palavras-Chave: epibentos; ecossistema estuarino; diversidade; variáveis ambientais

\section{INTRODUCTION}

Estuaries are recognised as transition zones, or ecotones, between freshwater and marine habitats (Dyer 1997; Elliott \& McLusky 2002; Meire et al. 2005). The species that live in estuaries need to be adapted to rigorous variations in salinity (physiological stress), water movement and turbidity (physical stress) (McLusky 1993; Constable 1999; Little 2000; Meire et al. 2005). Estuaries support many important ecosystem functions such as biogeochemical cycling and nutrient movement, flood mitigation, maintenance of biodiversity and biological production (Meire et al. 2005). Estuaries also provide nursery grounds for several commercial fish and crustacean species and serve as an important link between rivers and the sea for many anadromous and catadromous species (McLusky 1999; Meire et al. 2005; Leitão et al. 2006; Cabral et al. 2007; Martinho et al. 2007). Epibenthic fauna is the most important component of the estuarine community and represents a link between different life stages of some species and different niches (Costa-Dias et al. 2010a). Benthos are an important part of the fish and benthic invertebrate food web, which are used by humans as a food source, making them economically relevant (McLusky 1999; Little 2000; Feller 2006). This intermediate position in food webs of epibenthos, makes them an important link in the process of pollutants and toxic compounds pathways in which they become elements of bioamplification and of bioaccumulation of contaminants (Costa-Dias et al. 2010a). Environmental changes by natural or anthropogenic disturbances are able to modify these communities, and may induce negative impacts on the entire ecosystem. Therefore it is necessary to increase knowledge about the ecology of epibenthic communities, particularly in poorly known estuaries.

Previous studies have shown that Pomatoschistus microps (Krøyer, 1838) is the most abundant species in the epibenthic fish community of the Cávado estuary (Coelho \& Santos 2006). No published information is, however, available for the epibenthic invertebrate community of this estuary.

The aims of this study were as follows: (1) obtain an inventory of the epibenthic fauna in protected area of the lower Cávado estuary, (2) contribute to the characterisation of the spatial and seasonal distribution of the epibenthic biodiversity and (3) relate the diversity, abundance and biomass distribution of the epibenthic community to environmental information such as temperature, salinity, dissolved oxygen, precipitation and sediment type.

\section{MATERIALS AND METHODS}

\subsection{Study area}

The Cávado River originates in Serra de Larouco, North Portugal, at an altitude of about $1520 \mathrm{~m}$ and courses
$-129 \mathrm{~km}$ to its mouth in Esposende. Its basin covers an area of $-1589 \mathrm{~km}^{2}$, representing $1.8 \%$ of the territory of Portugal. The annual average flow at the mouth is $-71 \mathrm{~m}^{3} / \mathrm{s}$. The Cávado estuary is integral to the 'Natural Park of the North Coast' (Parque Natural Litoral Norte, PNLN) and is classified as CORINE Biotope No. 136, "Foz do Cávado / Costa Esposende" and was designated as site "Litoral Norte" (code PTCON0017) of the Natura 2000 network.

\subsection{Sampling and laboratory analysis}

Sixteen monthly samples were collected between February 2009 and September 2010 from five stations located along the estuary (E1, E2 and E3 at the margin and E1a and E3a within the channel (Figure 1). Samples were gathered with a dredge $(40 \mathrm{~cm}$ wide by $20 \mathrm{~cm}$ tall) with a $1 \mathrm{~m}$ long bag that had a mesh size of $10 \mathrm{~mm}$. The dredge was towed on the estuary bottom by means of a wire cable operated by hand aboard a slowly moving boat against the river flow. The sampling effort used on the present work was a drag for 1 minute at constant velocity of 1 knot $\left(12.3 \mathrm{~m}^{2}\right)$. The dragging was conducted during the diurnal tide. Biological samples were fixed in 10\% formalin. During sampling, water temperature, salinity and dissolved oxygen were recorded close to the estuary bottom using a multi-parameter probe (Yellow Springs Instruments, Model 85). At each sampling station $1.5 \mathrm{~kg}$ of sediment was collected for granulometric analysis at the beginning of this study.

In the laboratory, the samples were gently washed in running tap water through a sieve (mesh size of $0.5 \mathrm{~mm}$ ) and then the biological material was sorted in a tray with backlight. The epienthic fauna was identified to the lowest taxonomic level and all individuals were weighed $(0.001 \mathrm{~g})$. Data on individuals per species were used to calculate the biological parameters of abundance (individuals $/ \mathrm{m}^{2}$ ) and biomass $\left(\mathrm{g} / \mathrm{m}^{2}\right)$. Small sized benthic species, typical infauna like Amphipoda, Isopoda, Gastropoda, Bivalvia and Annelida were not considered for data analysis because the dredge is not adequate for their assessment (Costa-Dias et al. 2010a). This infauna species were presented only in Appendix A to complete the inventory of the benthic species of Cávado estuary. Sediment samples were dried in an oven at $62^{\circ} \mathrm{C}$ to constant weight and then sieved. Grain size analysis was carried out by mechanical separation through a column of six sieves with different mesh sizes. Sediment was divided in seven different classes according grain size: gravel $(>2 \mathrm{~mm})$, very coarse sand $(1-2 \mathrm{~mm})$, coarse sand $(0.5-1.0 \mathrm{~mm})$, medium sand $(0.25-0.5 \mathrm{~mm})$, fine sand $(0.125-0.250 \mathrm{~mm})$, very fine sand $(0.063-0.125 \mathrm{~mm})$ and silt $(>0.063 \mathrm{~mm})$ (Blott $\&$ Pye 2001). Dry weight of each fraction of the sediment samples were expressed as percentage of the total sample's weight. 


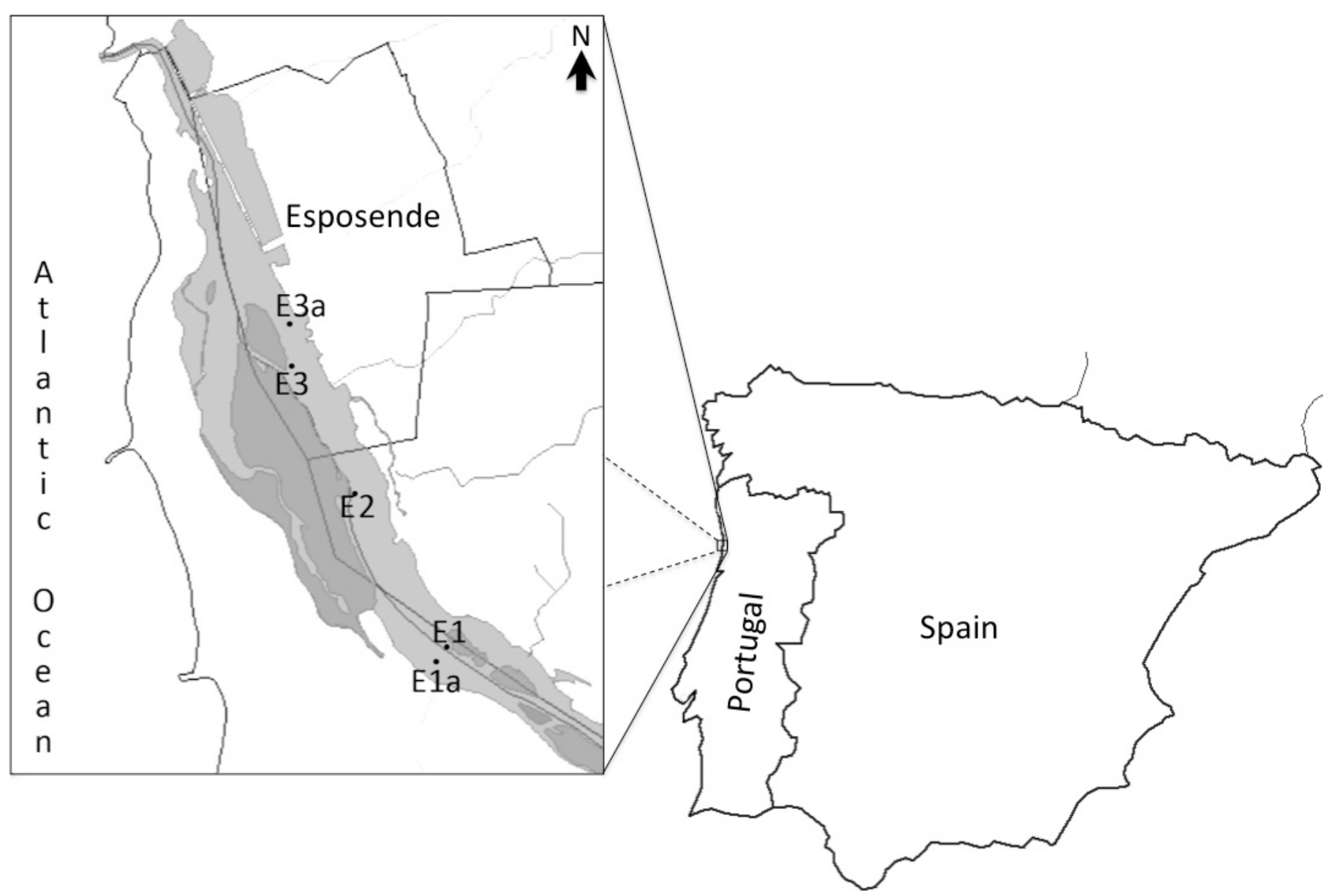

Figure 1. Map of the lower Cávado estuary showing the five sampling stations: E1, E2 \& E3 on margins \& E1a \& E3a on the channel. Figura 1. Mapa do estuário inferior do Cávado assinalando as cinco estaçóes de amostragem: E1, E2 e E3 nas margens e E1a e E3a no canal.

\subsection{Data analysis}

PRIMER v6 software was used for data analysis to calculate Margalef species richness (R), the indices of Shannon-Wiener diversity (H'), Simpson's dominance (D) and Pielou's evenness (J') (Clarke \& Gorley 2001). The same software was used to perform MDS analysis using abundance data after square-root transformation and Bray-Curtis similarity calculation to identify and characterize spatial and seasonal patterns and affinity assemblages. ANOSIM were used to analyse spatial and seasonal variation and differences between epibenthic assemblages and the species contributing to similarities within assemblages were identified by SIMPER analysis (cut-off 90\%) (Clarke 1993).

Comparisons between values of abundance, biomass and Shannon diversity index of stations and months were conducted using the non parametric analysis Kruskal-Wallis test. The relationship between abundance and biomass and between abundance, biomass, Shannon diversity index and type of sediment was established by the Pearson's correlation coefficient. All comparisons were made using STATISTICA 10.0 software (Statsoft 2012).
In order to establish correlations between the abundance and the environmental variables (temperature, salinity, dissolved oxygen and precipitation), BIOENV procedure with Primer Software (Clarke 1993) was used applying the Spearman rank correlation. We used the abundance data, square-root transformed, and the Bray-Curtis similarity. For abiotic data we used a normalised Euclidean distance matrix. This analysis was complemented by the calculation of a correlation matrix among the biological data (abundance, biomass, species richness, equitability and diversity indexes) and the environmental data using STATISTICA 10.0 software (Statsoft 2012).

\section{RESULTS}

\subsection{Environmental analysis}

Water temperature values ranged between $10.0^{\circ} \mathrm{C}$, in January 2010 at station E1 and E1a, and $20.5^{\circ} \mathrm{C}$, in July 2010 at station E3 and E3a, and variation between stations is low. Mean values and standard deviation, considering all station at each month are displayed in Figure 2. Salinity 
values ranged from zero, when precipitation was higher, to 34.0 in May 2009 at station E3. Dissolved oxygen values in the water ranged between $5.10 \mathrm{mg} / \mathrm{L}$ in September 2009 and $12.5 \mathrm{mg} / \mathrm{L}$ in January and April 2010, at stations E1 and E1a. Highest levels of precipitation occurred during the winter and spring months. The maximum level of precipitation occurred in December 2009 (65 mm; total rainfall registered in the last seven days before the sampling day). Despite the high levels of precipitation recorded in July 2009, summer and early fall are typically characterised by little to no rainfall (IPMA, s/d).

Granulometric analysis showed sampling stations E1, $\mathrm{E} 1 \mathrm{a}$ and $\mathrm{E} 2$ to be characterised by gravel $(\geq 2 \mathrm{~mm})$ (Table 1$)$. Stations E3 and E3a, despite being mostly gravel ( $\geq 2 \mathrm{~mm}$ ), also contained silt $(<0.063 \mathrm{~mm})$. The margin station (E3) had a higher percentage of silt than the channel station (E3a).
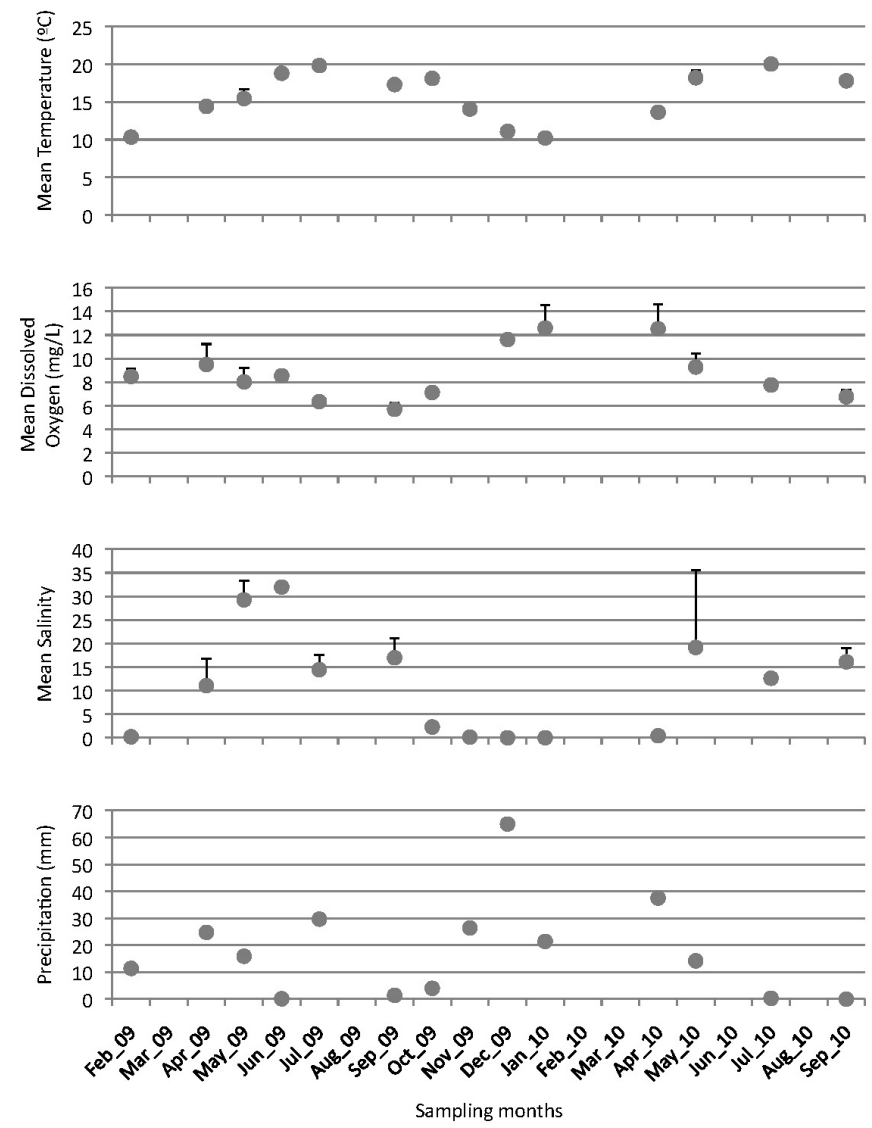

Figure 2. Environmental data for the Cávado estuary: mean water temperature $\left({ }^{\circ} \mathrm{C}\right)$, mean dissolved oxygen in water $(\mathrm{mg} / \mathrm{L})$, mean water salinity \& precipitation $(\mathrm{mm})$.

Figura 2. Dados ambientais do estuário do Cávado: temperatura média da água $\left({ }^{\circ} \mathrm{C}\right)$, oxigénio dissolvido médio na água $(\mathrm{mg} / \mathrm{L})$, salinidade média da água e precipitação $(\mathrm{mm})$.
Table 1. Dry weight of grain size fractions expressed by percentage at each sampling station.

Tabela 1. Peso seco de cada fraçẫo de tamanho de gräo, expresso em percentagem, por estação de amostragem.

\begin{tabular}{l|c|c|c|c|c} 
& E1 & E1a & E2 & E3 & E3a \\
\hline $\begin{array}{l}\text { Gravel }(> \\
\text { 2mm) }\end{array}$ & 92.87 & 88.84 & 99.93 & 42.73 & 76.64 \\
\hline $\begin{array}{l}\text { Very coarse } \\
\text { sand }(1- \\
2 \mathrm{~mm})\end{array}$ & 5.54 & 8.72 & 0.00 & 19.17 & 10.88 \\
\hline $\begin{array}{l}\text { Coarse sand } \\
(0.5-1 \mathrm{~mm})\end{array}$ & 1.16 & 2.24 & 0.04 & 11.93 & 5.22 \\
\hline $\begin{array}{l}\text { Medium } \\
\text { sand }(0.25-\end{array}$ & 0.37 & 0.17 & 0.00 & 7.37 & 2.55 \\
$0.5 \mathrm{~mm})$ & 0.02 & 0.03 & 0.01 & 4.22 & 0.91 \\
\hline $\begin{array}{l}\text { Fine sand } \\
(0.125-\end{array}$ & & & & & \\
$0.25 \mathrm{~mm})$ & 0.04 & 0.00 & 0.01 & 11.33 & 2.63 \\
\hline $\begin{array}{l}\text { Very fine } \\
\text { sand }(0.063- \\
0.125 \mathrm{~mm})\end{array}$ & 0.00 & 0.00 & 0.00 & 3.24 & 1.17 \\
\hline $\begin{array}{l}\text { Silt }(< \\
0.063 \mathrm{~mm})\end{array}$ & & & &
\end{tabular}

\subsection{Spatial and seasonal variations in epibenthic community structure}

The biological data set consisted of 7352 individuals (Appendix A), with a total biomass of 3682.621g from 15 taxa that included Arthropoda (8) and Vertebrata (7). Crangon crangon was the most abundant species, representing $75 \%$ of the total number of individuals collected. This was followed by Carcinus maenas (6\%) and Pomatoschistus microps (8\%) and Neomysis integer (5\%). Carcinus maenas dominated the epibenthic biomass of the Cávado estuary, making up 71\% of the total biomass collected, followed by Crangon crangon (14\%), Anguilla anguilla (5\%) and Pomatoschistus microps $(5 \%)$.

Based on similarity analysis of abundance data, two assemblages could be distinguished by MDS analysis (stress value $=0.00$ ): Assemblage A corresponding to stations E1 and E1a, and Assemblage B corresponding to stations E2, E3 and E3a as shown in Figure 3. However, ANOSIM did not confirm significant differences between the two assemblages $(\mathrm{R}=0.75 \mathrm{p}<0.1)$. SIMPER analysis showed that the species contributing the most to the average similarity within assemblage $\mathrm{A}$ and within assemblage $\mathrm{B}$ were $C$. crangon, C. maenas and P. microps (Table 2). The species responsible for the $90 \%$ cut-off for the dissimilarity observed between assemblages were the three above mentioned ones and also $N$. integer. Collectively, the stations nearest the mouth (E2/E3/ E3a) had higher abundance values (15.9ind./ $\mathrm{m}^{2}$ ) (Figure 4) and were dominated by $C$. crangon, whereas stations further 
upstream (E1/E1a) had a lower abundance $\left(2.8\right.$ ind. $\left./ \mathrm{m}^{2}\right)$ but were also dominated by $C$. crangon. Samples from marginal stations had higher values of abundance (E1 1.7 ind. $/ \mathrm{m}^{2}$; E3 9.0ind. $/ \mathrm{m}^{2}$ ) compared to samples from the channel stations (E1a 1.0ind. $/ \mathrm{m}^{2}$; E3a $2.4 \mathrm{ind} . / \mathrm{m}^{2}$ ). There were, however, no significant differences between samples $(\mathrm{H}(\mathrm{df}=4, \mathrm{~N}=75)$ $=3.264 \mathrm{p}=0.515)$. The stations closest to the mouth $(\mathrm{E} 2 /$ $\mathrm{E} 3 / \mathrm{E} 3 \mathrm{a})$ showed higher values for mean biomass $\left(8.2 \mathrm{~g} / \mathrm{m}^{2}\right)$ when compared to upstream stations (E1/E1a) $\left(1.1 \mathrm{~g} / \mathrm{m}^{2}\right)$. Downstream, the channel station had higher biomass values than the margin. Upstream, the opposite was observed. The samples were not significantly different in terms of biomass $(\mathrm{H}(\mathrm{df}=4, \mathrm{~N}=75)=4.270 \mathrm{p}=0.371)$. The Shannon diversity index value was highest at station E1 (1.360) and lowest near the mouth at station E3 (0.711). However, E1 had the highest value of species richness (1.684) and E1a registered the lower value (0.999). Additionally, the relative abundance at the mouth (E3) demonstrated a large difference between the various species. The most abundant $(C$. crangon) reached $70 \%$ and, therefore, lowered equitability $(0.277)$. Values for the Shannon diversity index were not significantly different between the sampling stations $(\mathrm{H}(\mathrm{df}=4, \mathrm{~N}=57)=3.578$ $\mathrm{p}=0.467$ ). Accordingly, the Simpson diversity index values ranged between 0.677 at station E1 and 0.312 at station E3 and equitability value was higher at station E1a (0.553).

MDS analysis (stress value $=0.09$ ) was performed, using similarity matrix of abundance data to assess the seasonal distribution. Three assemblages could be distinguished: Assemblage I corresponding to February 2009 and January and April 2010; Assemblage II corresponding to March, April, May, August and December 2009 and May 2010; Assemblage III corresponding to June, July, September, October, November 2009 and July and September 2010 as shown in Figure 5. ANOSIM confirmed significant differences between the three assemblages $(\mathrm{R}=0.79 \mathrm{p}<0.001)$. SIMPER analysis showed that the species contributing the most to the average similarity within assemblage I were Pomatoschistus microps and Neomysis integer and within assemblage II and III were Crangon crangon, Carcinus maenas and also $P$. microps and $N$. integer (Table 3). In addition to these four taxa, other species were also responsible for the $90 \%$ cutoff for the dissimilarity observed between assemblages. It is the case of Anguilla anguilla, Pomatoschistus minutus and Platichthys flesus, between I and II, A. anguilla, Palaemon

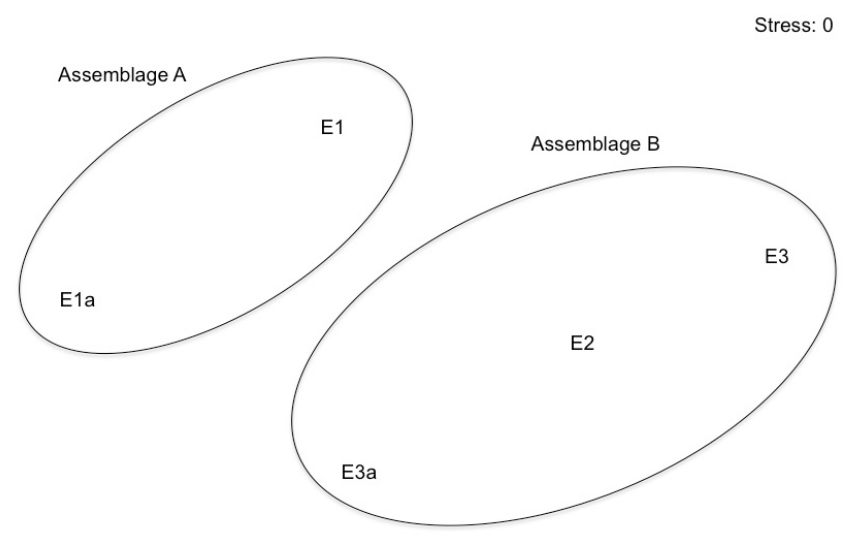

Figure 3. MDS plot of epibenthos similarity among 5 sampling stations of Cávado estuary, based on abundance data.

Figura 3. Gráfico MDS da similaridade de epibentos entre as 5 estaçóes de amostragem do estuário do Cávado, utilizando os dados de abundância.

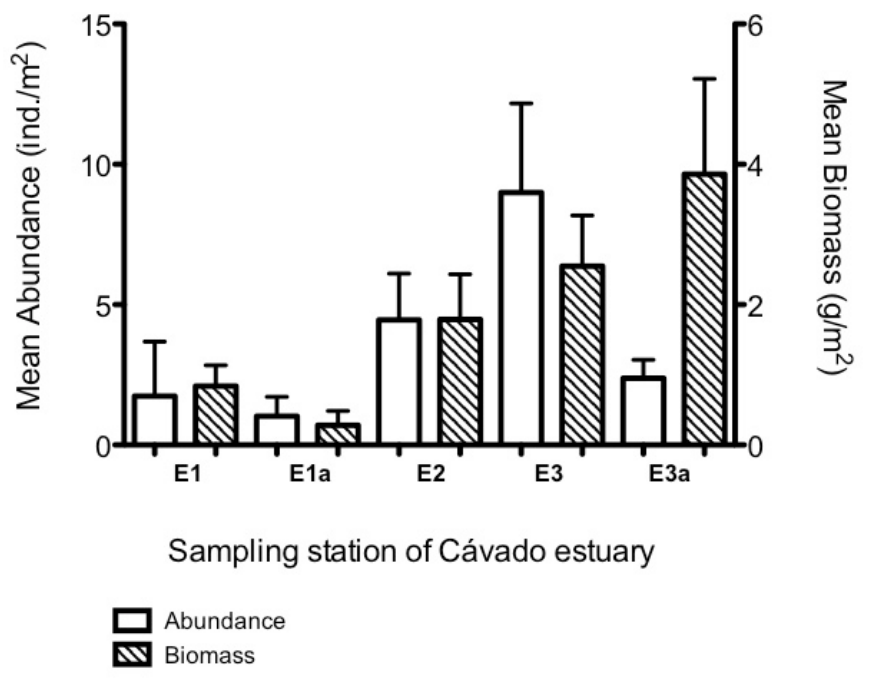

Figure 4. Mean abundance (ind. $\left./ \mathrm{m}^{2}\right) \&$ mean biomass $\left(\mathrm{g} / \mathrm{m}^{2}\right) \&$ respective standard deviation bars of sampling stations of Cávado estuary.

Figura 4. Abundância média (ind. $\left./ \mathrm{m}^{2}\right)$ e biomassa media $\left(\mathrm{g} / \mathrm{m}^{2}\right)$ e respectivo desvio padrão para as estaçóes de amostragem do estuário do Cávado.

Table 2. Species which cumulative contributions totalised $90 \%$ similarity within the Assemblage A \& within the Assemblage B \& also between Assemblages dissimilarity. Tabela 2. Espécies que cumulativamente contribuem $90 \%$ para a similaridade dentro do Grupo A e dentro do Grupo B e ainda para a dissimilaridade entre os grupos.

\begin{tabular}{l|c|c|c}
\hline \multirow{2}{*}{ Species } & \multicolumn{2}{|l|}{ Similarity within } & Dissimilarity between \\
\cline { 2 - 4 } & Assemblage A & Assemblage B & Assemblage A \& B \\
\hline Crangon crangon & 74.39 & 75.10 & 75.72 \\
\hline Carcinus maenas & 9.54 & 11.01 & 8.37 \\
\hline Pomatoschistus microps & 9.26 & 6.20 & 5.30 \\
\hline Neomysis integer & - & - & 4.46
\end{tabular}


serratus and Palaemon elegans between assemblages I and III and P. minutus, P. flesus, P. serratus, P. elegans and Syngnathus acus between assemblages II and III. July, September and October 2009 and September 2010 showed the highest mean abundances of epibenthos (8.1ind. $/ \mathrm{m}^{2}$; 7.9ind./ $\mathrm{m}^{2}$, 12.3ind. $/ \mathrm{m}^{2}$ and $11.4 \mathrm{ind} . / \mathrm{m}^{2}$ respectively) as shown in Figure 6. We recorded 0.6ind. $/ \mathrm{m}^{2}$ in February 2009, 0.2 ind. $/ \mathrm{m}^{2}$ in January 2010 and $0.4 \mathrm{ind} . / \mathrm{m}^{2}$ in April 2010, the months with the lowest mean abundance. There were no significant differences in abundance within the studied period $(\mathrm{H}(\mathrm{df}=15, \mathrm{~N}=240)=13.642 \mathrm{p}=0.553)$. April and October 2009 and May and July 2010 had the highest levels of epibenthos biomass $\left(3.9 \mathrm{~g} / \mathrm{m}^{2}, 6.6 \mathrm{~g} / \mathrm{m}^{2}, 3.2 \mathrm{~g} / \mathrm{m}^{2}\right.$ and $4.3 \mathrm{~g} / \mathrm{m}^{2}$, respectively). February 2009 and January and April 2010 had lower values $\left(0.2 \mathrm{~g} / \mathrm{m}^{2} ; 0.1 \mathrm{~g} / \mathrm{m}^{2}\right.$ and $0.2 \mathrm{~g} / \mathrm{m}^{2}$, respectively). There were no significant differences in biomass within the period studied $(\mathrm{H}(\mathrm{df}=15, \mathrm{~N}=240)=14.907$ $\mathrm{p}=0.458$ ). The highest Shannon diversity index values were obtained in May 2009 (1.277) and April 2009 (1.269) and the lowest in October 2009 (0.387) and January 2010 (0.440). Shannon diversity index values between sampling months were not significantly different $(\mathrm{H}(\mathrm{df}=15, \mathrm{~N}=57)$ $=19.432 \mathrm{p}=0.195)$. May 2009 had the highest recorded species richness (1.267) and September 2009 the highest number of species (9). January 2010 had the lowest species richness (0.311) and also the lowest number of species (2). Accordingly, the values of Simpson diversity index ranged between 0.679 in April 2009 and 0.155 in October 2009. Equitability values varied from 0.847 in April 2010 and 0.199 in October 2009.

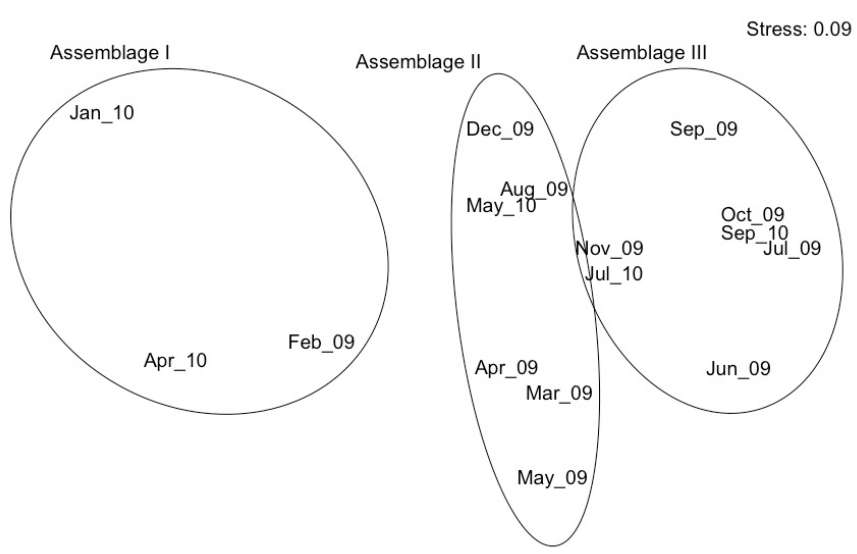

Figure 5. MDS plot of epibenthos similarity among 16 sampling months at Cávado estuary, based on abundance data.

Figura 5. Gráfico MDS da similaridade de epibentos entre os 16 meses de amostragem no estuário do Cávado, utilizando os dados de abundância.

The correlation between epibenthic abundance and biomass was low $(\mathrm{R}=0.23, \mathrm{~N}=67 \mathrm{p}=0.066)$.

The BIOENV procedure revealed that the environmental variables that most contribute to the spatial distribution and seasonal variation of biological data were dissolved oxygen, temperature and salinity with a combined correlation value of 0.172 (Table 4). However, dissolved oxygen is the parameter that explains most of the variability $(0.147)$. The

Table 3. Species which cumulative contributions totalised $90 \%$ similarity within the Assemblage I, within the Assemblage II $\&$ within the Assemblage III \& also between Assemblages dissimilarity.

Tabela 3. Espécies que cumulativamente contribuem 90\% para a similaridade dentro do Grupo I, dentro do Grupo II e dentro do Grupo III e ainda para a dissimilaridade entre os grupos.

\begin{tabular}{|c|c|c|c|c|c|c|}
\hline & \multicolumn{3}{|c|}{ Similarity within } & \multicolumn{3}{|c|}{ Dissimilarity between } \\
\hline & $\begin{array}{c}\text { Assemblage } \\
\text { I }\end{array}$ & $\begin{array}{c}\text { Assemblage } \\
\text { II }\end{array}$ & $\begin{array}{c}\text { Assemblage } \\
\text { III }\end{array}$ & $\begin{array}{c}\text { Assemblage I } \\
\& \text { II }\end{array}$ & $\begin{array}{l}\text { Assemblage I } \\
\& \text { III }\end{array}$ & $\begin{array}{l}\text { Assemblage II } \\
\& \text { III }\end{array}$ \\
\hline Crangon crangon & - & 43.21 & 59.36 & 32.99 & 52.73 & 44.46 \\
\hline Carcinus maenas & - & 20.67 & 14.50 & 18.00 & 17.07 & 11.49 \\
\hline $\begin{array}{l}\text { Pomatoschistus } \\
\text { microps }\end{array}$ & 86.08 & 22.18 & 12.66 & 9.60 & 4.75 & 7.11 \\
\hline Neomysis integer & 13.92 & 10.77 & 9.07 & 18.58 & 6.44 & 11.54 \\
\hline Anguilla anguilla & - & - & - & 4.58 & 2.71 & - \\
\hline $\begin{array}{l}\text { Pomatoschistus } \\
\text { minutus }\end{array}$ & - & - & - & 4.00 & - & 3.02 \\
\hline Platichthys flesus & - & - & - & 3.90 & - & 2.83 \\
\hline Palaemon serratus & - & - & - & - & 5.09 & 6.12 \\
\hline Palaemon elegans & - & - & - & - & 2.33 & 2.96 \\
\hline Syngnathus acus & - & - & - & - & - & 2.20 \\
\hline
\end{tabular}




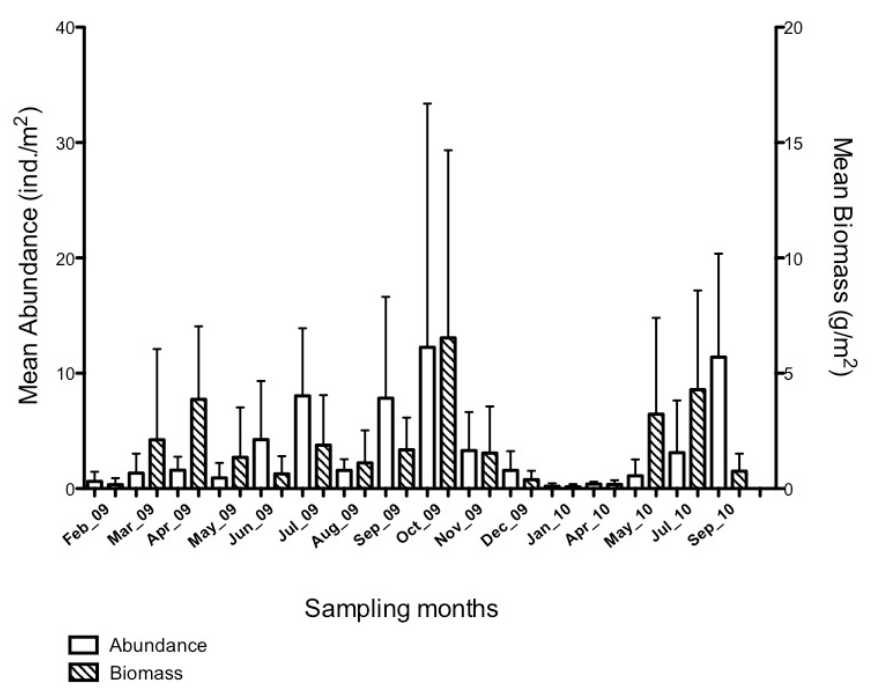

Figure 6. Mean abundance (ind. $\left./ \mathrm{m}^{2}\right) \&$ mean biomass $\left(\mathrm{g} / \mathrm{m}^{2}\right) \&$ respective standard deviation bars of sampling months at Cávado estuary.

Figura 6. Abundância média (ind. $\left./ \mathrm{m}^{2}\right)$ e biomassa média $\left(\mathrm{g} / \mathrm{m}^{2}\right)$ e respectivo desvio padráo para os meses de amostragem no estuário do Cávado.

matrix of correlations between biological data (abundance, biomass, species richness, equitability and diversity indexes) and environmental parameters showed that abundance of epibenthos was positively correlated to water temperature $(\mathrm{R}=0.31, \mathrm{~N}=42 \mathrm{p}=0.044)$. Biomass was also correlated with water temperature $(\mathrm{R}=0.31, \mathrm{~N}=42 \mathrm{p}=0.047)$. The number of species was positively correlated with water temperature $(\mathrm{R}=0.38, \mathrm{~N}=42 \mathrm{p}=0.013)$ and negatively correlated with dissolved oxygen $(\mathrm{R}=-0.40, \mathrm{~N}=42 \mathrm{p}=0.009)$. Pielou's equitability was positively correlated with dissolved oxygen $(\mathrm{R}=0.43, \mathrm{~N}=42 \mathrm{p}=0.004)$ and Simpson diversity index was also positively correlated with this abiotic variable $(\mathrm{R}=$ $0.37, \mathrm{~N}=42 \mathrm{p}=0.015)$. The remaining diversity indices did not have a significant correlation with the physicochemical data. Relating biological data with the type of sediment, the abundance was correlated with a high significance with fine sand and very fine sand, $(\mathrm{R}=0.89, \mathrm{~N}=5 \mathrm{p}=0.041)$ and $(\mathrm{R}=0.89, \mathrm{~N}=5 \mathrm{p}=0.042)$ respectively. Biomass was better correlated with silt $(\mathrm{R}=0.57, \mathrm{~N}=5 \mathrm{p}=0.316)$. The number of species was better correlated with medium sand $(\mathrm{R}=0.58$, $\mathrm{N}=5 \mathrm{p}=0.306$ ). Pielou's equitability was better negative correlated with very fine sand $(R=-0.85, N=5 p=0.068)$. Shannon diversity index and Simpson diversity index were better negative correlated with fine sand, $(R=-0.78, N=5 p=$ $0.116)$ and $(R=-0.76, N=5 p=0.134)$ respectively. Margalef species richness was very low correlated with any grain size of sediment.

\section{DISCUSSION}

This work is relevant for the study of estuarine epibenthos in Portugal, adding new information on the ecology and spatial and seasonal distribution patterns along the estuarine gradient in a poorly known estuary of Northwest Portugal.

According to our results, during the sampling period, water temperature and salinity showed higher values during the summer months and lower values during the winter as expected. We did not observe a water temperature gradient or large variations among the sampling stations. In general, salinity was lower at most upstream stations (E1, E1a) and higher at most downstream stations (E2, E3 and E3a). Seasonal variations and along to the estuarine gradient as those indicated are very common in Portuguese estuaries (Moreira et al. 1993; Azevedo et al. 2008; Chainho et al. 2008; Sousa et al. 2008b; Costa-Dias et al. 2010b; Medeiros et al. 2012). Winter and spring were the wettest seasons compared to summer, which was generally drier. This follows the pattern of most temperate estuaries, and is characterised by having a significant influx of freshwater during the winter, which has an impact on salinity variation (Elliott \& McLusky 2002; Chainho et al. 2006; Teixeira et al. 2008). The presence of gravel at upstream stations and the accumulation of muddy sediments in the stations near of mouth of Cávado estuary detected in the present study has also been observed in other Portuguese estuaries (Sousa et al. 2006; Chainho et al. 2007; Sousa et al. 2008b; Teixeira et al. 2008).

Table 4. Combination of variables $(k)$ providing the highest values for the correlation (using the Spearman rank correlation) between abundance $\&$ environmental data, summarizing the results of BIOENV analysis.

Tabela 4. Combinação das variáveis ( $k$ ) que fornecem os valores mais elevados de correlação (utilizando a correlação de Spearman) entre a abundância e os dados ambientais, resumindo os resultados da análise BIOENV.

\begin{tabular}{c|c|c|c|c|c|c}
\hline$k$ & \multicolumn{2}{|l}{ Best variables combination } \\
\hline 1 & 0.147 & Dissolved Oxygen & 0.095 & Temperature & 0.049 & Salinity \\
\hline 2 & 0.161 & $\begin{array}{c}\text { Temperature } \\
\text { Dissolved Oxygen }\end{array}$ & 0.161 & $\begin{array}{c}\text { Dissolved Oxygen } \\
\text { Salinity }\end{array}$ & 0.112 & $\begin{array}{c}\text { Dissolved Oxygen } \\
\text { Precipitation }\end{array}$ \\
\hline 3 & $\mathbf{0 . 1 7 2}$ & $\begin{array}{c}\text { Temperature } \\
\text { Dissolved Oxygen } \\
\text { Salinity }\end{array}$ & 0.126 & $\begin{array}{c}\text { Temperature } \\
\text { Dissolved Oxygen } \\
\text { Precipitation }\end{array}$ & 0.121 & $\begin{array}{c}\text { Dissolved Oxygen } \\
\text { Salinity } \\
\text { Precipitation }\end{array}$
\end{tabular}


Our results show the representativeness of epibenthic crustaceans and gobies, but not the other species of fish, particularly in adult size. Most eels and flatfishes caught were juveniles. Care must be taken to analyze and compare present data with similar studies, once the gear type, mesh size, speed and depth of sampling chosen could be different. The epibenthic fauna of Cávado estuary was characterised by the dominance of Crangon crangon in abundance and Carcinus maenas in biomass. These were also the species that dominated the epibenthic community of Minho estuary (Costa-Dias et al. 2010a). The presence of exotic species was not recorded in Cávado. In Minho, Costa-Dias et al. (2010a) detected the presence of the introduced freshwater crayfish Procambarus clarkii in some of the upper sites. Further studies could be useful in Cávado estuary, with sampling stations further upstream to assess the presence of exotic species.

Although we did not find significant differences, multivariate analysis indicated two assemblages of epibenthic fauna in Cávado estuary: one corresponding to the upstream stations (Assemblage A) and the other to the stations close to the estuary mouth (Assemblage B). The dissimilarity within these two groups is a result of the same species (Crangon crangon, Carcinus maenas, Pomatoschistus microps and Neomysis integer) but in different proportions. All of them are typically euryhaline species, common in epibenthic communities of temperate European estuaries (Hampel et al. 2009). Comparatively, in Minho dissimilarity between groups is a result of the presence of different species. According to Costa-Dias et al. (2010a), the group of stations with a higher influence of freshwater was dominated by the Atyaephyra desmarestii and the group of stations with a higher marine influence was dominated by $C$. crangon and $P$. microps, but their work extended well upstream. In Cávado, a few individuals of $A$. desmarestii were collected, regardless of location, in months that have been registered a very low salinity, i.e. more influenced by higher upstream freshwater input.

Considering all the species, the stations located on the marginal sand banks had higher abundance than stations located in the channel. This could be related to higher channel's average depth and stronger water flow. Variations in the distribution of biomass along the estuarine area were due not only to the presence of adult $C$. maenas, mainly in the channel, but also of Anguilla anguilla and Platichthys flesus near the margins. The Shannon diversity index was higher at upstream stations and lower near the mouth due to the $C$. crangon higher abundance downstream. Different patterns of sediment deposition and current strength at the narrow mouth of the Cávado estuary are possible additional causes of these findings. Contrary, in Minho the highest values were recorded at downstream stations (Costa-Dias et al. 2010a). Although we have recorded a lower number of species for Cávado, we registered a higher value of Shannon diversity to those found in Minho estuary. However, epibenthic diversity of Cávado was low as compared to other European estuaries (Maes et al. 1998).

Analysing the seasonal variation of abundance, three dissimilar epibenthic assemblages were found in Cávado estuary: Assemblage I corresponded mainly to winter months, Assemblage II mostly related to the spring months but included also other months that showed abundance pattern closest to spring and Assemblage III related to both summer and autumn months. Abundance was higher in the summer and early autumn and lower in the winter. The spring assemblage (II) pattern is influenced by the presence of young A. anguilla and P. flesus at this season, as in other estuaries (Martinho et al. 2007; Freitas et al. 2009; Ramos et al. 2010). The variation of epibenthic biomass did not present a clear seasonal pattern, being higher in months when there was the presence of species heavier individuals as C. maenas, A. anguilla, P. flesus, and Solea solea. Along the sampling months, the Shannon diversity index was higher in spring and summer and lower in autumn and winter. Species numbers were, however, higher in summer and autumn and lower in winter and spring.

The environmental parameter with more contribution to the distinction of spatial and seasonal assemblages was dissolved oxygen (correlated with water temperature and salinity). Even so, biological data, such as abundance and biomass, were better correlated with temperature than with salinity. Several studies reported the water temperature and salinity as the most important abiotic factors affecting Portuguese estuarine fauna (Sousa et al. 2006; Sousa et al. 2008b; Teixeira et al. 2008; Costa-Dias et al. 2010a), not dissolved oxygen. The sediment type was also important in spatial distribution of epibenthic communities, being the abundance, biomass and the diversity indexes better correlated with the presence of fine sediment $(<0.125 \mathrm{~mm})$. The differences found were expected since the hydrodynamic fluctuations have an important effect on the cycles of sediment erosion and deposition and, hence, on the colonisation of benthic communities (Chainho et al. 2006).

Pollution can contribute to a loss of biodiversity. It can cause the exclusion of sensitive species that are not able to survive or to adapt to certain levels of pollution, can alter abiotic factors to which some species have a low range of tolerance, or can interfere in interspecific relationships (Sousa et al. 2008a). In the Douro and Mondego estuaries, an increased concentration of pollutants has effects on benthic community structure, namely in terms of a low diversity and the presence of opportunistic species (Mucha et al. 2003; Mucha et al. 2004; Mucha et al. 2005; Chainho et al. 2007). There are a few studies showing the existence of heavy metals and organochlorine pesticides in the fine sediments of the Cávado estuary (Almeida et al. 2008; Carvalho et al. 2009). The stations examined here, however, were not the same as the sampling stations of that work since such contaminants typically accumulate in fine sediments on the banks of the estuary mouth and our sampling stations were located in zones with low fine sediment contents. The results of the present work suggest, however, that further studies are needed to determine the effects of contaminant bioaccumulation in estuary sediments on the most abundant crustacean, Crangon crangon. This species may be considered as a bioindicator of the quality of the estuarine system, as reported for other European estuaries (Culshaw et al. 2002; Quintaneiro et al. 2006; Jung \& Zauke 2008; Jung et al. 2009; Caçador et al. 2012).

The seasonal variation in diversity identified for the Cávado estuary demonstrates the dynamics of this ecosystem. 
Like other Portuguese estuaries (Cabral et al. 2007; Ramos et al. 2010; França et al. 2011), the Cávado assumes regional importance as it acts as a nursery for several fishes species.

\section{ACKNOWLEDGEMENTS}

A special thanks to João Miquelino for loaning us a fishing boat so that we could collect the samples.

\section{REFERENCES}

Almeida, C.M.R.; Mucha, A.P.; Bordalo, A.A.; Vasconcelos, M.T.S.D. (2008) - Influence of a salt marsh plant (Halimione portulacoides) on the concentrations and potential mobility of metals in sediments. Science of the Total Environment, 403(1-3):188-195. DOI: 10.1016/j. scitotenv.2008.05.044

Azevedo, I.C.; Duarte, P.M.; Bordalo, A.A. (2008) Understanding spatial and temporal dynamics of key environmental characteristics in a mesotidal Atlantic estuary (Douro, NW Portugal). Estuarine, Coastal and Shelf Science, 76(3):620-633. DOI: 10.1016/j. ecss.2007.07.034

Blott, S.J.; Pye, K. (2001) - Gradistat: a grain size distribution and statistics package for the analysis of unconsolidation sediments. Earth Surface Processes and Landforms, 26(11):1237-1248. DOI: 10.1002/esp.261

Cabral, H.N.; Vasconcelos, R.; Vinagre, C.; França, S.; Fonseca, V.; Maia, A.; Reis-Santos, P.; Lopes, M.; Ruano, M.; Campos, J.; Freitas, V.; Santos, P.T.; Costa, M.J. (2007) - Relative importance of estuarine flatfish nurseries along the Portuguese coast. Journal of Sea Research, 57(23):209-217. DOI: 10.1016/j.seares.2006.08.007

Caçador, I.; Costa, J.L.; Duarte, B.; Silva, G.; Medeiros, J.P.; Azeda, C.; Castro, N.; Freitas, J.; Pedro, S.; Almeida, P.R.; Cabral, H.; Costa, M.J. (2012) - Macroinvertebrates and fishes as biomonitors of heavy metal concentration in the Seixal Bay (Tagus estuary): Which species perform better? Ecological Indicators, 19:184-190. DOI: 10.1016/j. ecolind.2011.09.007

Carvalho, P.N.;Rodrigues,P.N.R.;Basto,M.C.P.;Vasconcelos, M.T.S.D. (2009) - Organochlorine pesticides levels in Portuguese coastal areas. Chemosphere, 75(5):595-600. DOI: 10.1016/j.chemosphere.2009.01.060

Chainho, P.; Chaves, M.L.; Costa, J.L.; Costa, M.J.; Dauer, D.M. (2008) - Use of multimetric indices to classify estuaries with different hydromorphological characteristics and different levels of human pressure. Marine Pollution Bulletin, 56(6):1128-1137. DOI: 10.1016/j.marpolbul.2008.03.018

Chainho, P.; Costa, J.L.; Chaves, M.L.; Dauer, D.M.; Costa, M.J. (2007) - Influence of seasonal variability in benthic invertebrate community structure on the use of biotic indices to assess the ecological status of a Portuguese estuary. Marine Pollution Bulletin, 54(10):1586-1597. DOI: 10.1016/j.marpolbul.2007.06.009

Chainho, P.; Costa, J.L.; Chaves, M.L.; Lane, M.F.; Dauer, D.M.; Costa, M.J. (2006) - Seasonal and spatial patterns of distribution of subtidal benthic invertebrate communities in the Mondego River, Portugal - A poikilohaline estuary. Hydrobiologia, 555(1):59-74. DOI: 10.1007/s10750005-1132-2
Clarke, K.R. (1993) - Non-parametric multivariate analyses of changes in community structure. Australian Journal of Ecology, 18(1):117-143. DOI: 10.1111/j.14429993.1993.tb00438.x

Clarke, K.R.; Gorley, R.N. (2001) - PRIMER v5: User Manual/Tutorial. 91p., ed. Primer-e, Plymouth, U.K.

Coelho, C.; Santos, P. (2006) - Diversidade e abundância da ictiofauna em função de factores abióticos no estuário do Cávado. $2^{\circ}$ Congresso Ibérico de Ecologia. Livro de Resumos 56p., SPECO/AEET. Faculdade de Ciências da Universidade de Lisboa, Lisboa, Portugal.

Constable, A.J. (1999) - Ecology of benthic macroinvertebrates in soft-sediment environments: A review of progress towards quantitative models and predictions. Austral Ecology, 24(4):452-476. DOI: 10.1046/j.14429993.1999.00977.x

Costa-Dias, S.; Freitas, V.; Sousa, R.; Antunes, C. (2010a) - Factors influencing epibenthic assemblages in the Minho Estuary (NW Iberian Peninsula). Marine Pollution Bulletin, 61(4-6):240-246. DOI: 10.1016/j. marpolbul.2010.02.020

Costa-Dias, S.; Sousa, R.; Antunes, C. (2010b) - Ecological quality assessment of the lower Lima Estuary. Marine Pollution Bulletin, 61(4-6):234-239. DOI: 10.1016/j. marpolbul.2010.02.019

Culshaw, C.; Newton, L.C.; Weir, I.; Bird, D.J. (2002) Concentrations of $\mathrm{Cd}, \mathrm{Zn}$ and $\mathrm{Cu}$ in sediments and brown shrimp (Crangon crangon L.) from the Severn Estuary and Bristol Channel, UK. Marine Environmental Research, 54(3-5):331-334. DOI: 10.1016/S01411136(02)00163-0

Dyer, K.R. (1997) - Estuaries: a physical introduction. 2a ed., 195p., John Wiley and Sons, Chichester, England, U.K.. ISBN: 9780471974703.

Elliott, M.; McLusky, D.S. (2002) - The need for definitions in understanding estuaries. Estuarine, Coastal and Shelf Science, 55(6):815-827. DOI: 10.1006/ecss.2002.1031

Feller, R.J. (2006) - Weak meiofaunal trophic linkages in Crangon crangon and Carcinus maenus. Journal of Experimental Marine Biology and Ecology, 330(1):274283. DOI: $10.1016 /$ j.jembe.2005.12.033

França, S.; Costa, J.M.; Cabral, H.N. (2011) - Inter- and intra-estuarine fish assemblage variability patterns along the Portuguese coast. Estuarine, Coastal and Shelf Science, 91(2):262-271. DOI: 10.1016/j.ecss.2010.10.035

Freitas, V.; Costa-Dias, S.; Campos, J.; Bio, A.; Santos, P.; Antunes, C. (2009) - Patterns in abundance and distribution of juvenile flounder Platichthys flesus in Minho estuary (NW Iberian Peninsula). Aquatic Ecology, 43(4):1143-1153. DOI: 10.1007/s10452-009-9237-8

Hampel, H.; Elliott, M.; Cattrijsse, A. (2009) - Macrofaunal communities in the habitats of intertidal marshes along the salinity gradient of the Schelde estuary. Estuarine, Coastal and Shelf Science, 84(1):45-53. DOI: 10.1016/j. ecss.2009.05.029

IPMA (s/d) - Normais Climatológicas - 1971-2000 - Viana do Castelo / Meadela. In: O Clima, IPMA - Instituto Português do Mar e da Atmosfera homepage, Lisboa, Portugal. Available at http://www.ipma.pt/pt/oclima/ normais.clima/1971-2000/021/ (Accessed in January 2013) 
Jung, K.; Stelzenmuller, V.; Zauke, G.P. (2009) - Spatial analysis of metal concentrations in the brown shrimp Crangon crangon (Linnaeus, 1758) from the southern North Sea. Scientia Marina, 73(1):105-115. DOI: 10.3989/scimar.2009.73n1105

Jung, K.; Zauke, G.P. (2008) - Bioaccumulation of trace metals in the brown shrimp Crangon crangon (Linnaeus, 1758) from the German Wadden Sea. Aquatic Toxicology, 88(4):243-249. DOI: 10.1016/j.aquatox.2008.05.007

Leitão, R.; Martinho, F.; Neto, J.M.; Cabral, H.; Marques, J.C.; Pardal, M.A. (2006) - Feeding ecology, population structure and distribution of Pomatoschistus microps (Krøyer, 1838) and Pomatoschistus minutus (Pallas, 1770) in a temperate estuary, Portugal. Estuarine, Coastal and Shelf Science, 66(1-2):231-239. DOI: 10.1016/j. ecss.2005.08.012

Little, C. (2000) - The Biology of Soft Shores and Estuaries. Oxford University Press, New York. ISBN:0198504268.

Maes, J.; Taillieu, A.; Van Damme, P.A.; Cottenie, K.; Ollevier, F. (1998) - Seasonal Patterns in the Fish and Crustacean Community of a Turbid Temperate Estuary (Zeeschelde Estuary, Belgium). Estuarine, Coastal and Shelf Science, 47(2):143-151. DOI: 10.1006/ecss.1998.0350

Martinho, F.; Leitão, R.; Neto, J.M.; Cabral, H.N.; Marques, J.C.; Pardal, M.A. (2007) - The use of nursery areas by juvenile fish in a temperate estuary, Portugal. Hydrobiologia, 587(1):281-290. DOI: 10.1007/s10750007-0689-3

McLusky, D.S. (1993) - Marine and estuarine gradients - An overview. Netherlands Journal of Aquatic Ecology, 27(24):489-493. DOI: 10.1007/BF02334809

McLusky, D.S. (1999) - Estuarine benthic ecology: A European perspective. Austral Ecology, 24(4):302-311. DOI: $10.1046 / j .1442-9993.1999 .00983 . x$

Medeiros, J.P.; Chaves, M.L.; Silva, G.; Azeda, C.; Costa, J.L.; Marques, J.C.; Costa, M.J.; Chainho, P. (2012) - Benthic condition in low salinity areas of the Mira estuary (Portugal): Lessons learnt from freshwater and marine assessment tools. Ecological Indicators, 19(0):7988. DOI: 10.1016/j.ecolind.2011.09.008

Meire, P.; Ysebaert, T.; Van Damme, S.; Van Den Bergh, E.; Maris, T.; Struyf, E. (2005) - The Scheldt estuary: A description of a changing ecosystem. Hydrobiologia, 540(1-3):1-11. DOI: 10.1007/s10750-005-0896-8

Moreira, M.H.; Queiroga, H.; Machado, M.M.; Cunha, M.R. (1993) - Environmental gradients in a southern Europe estuarine system: Ria de Aveiro, Portugal implications for soft bottom macrofauna colonization. Netherlands Journal of Aquatic Ecology, 27(2-4):465-482. DOI: $10.1007 / \mathrm{BF} 02334807$
Mucha, A.P.; Bordalo, A.A.; Vasconcelos, M.T.S.D. (2004) Sediment quality in the Douro river estuary based on trace metal contents, macrobenthic community and elutriate sediment toxicity test (ESTT). Journal of Environmental Monitoring, 6(7):585-592. DOI: 10.1039/B401855A

Mucha, A.P.; Vasconcelos, M.T.S.D.; Bordalo, A.A. (2003) - Macrobenthic community in the Douro estuary: Relations with trace metals and natural sediment characteristics. Environmental Pollution, 121(2):169180. DOI: $10.1016 /$ S0269-7491(02)00229-4

Mucha, A.P.; Vasconcelos, M.T.S.D.; Bordalo, A.A. (2005) - Spatial and seasonal variations of the macrobenthic community and metal contamination in the Douro estuary (Portugal). Marine Environmental Research, 60(5):531550. DOI: 10.1016/j.marenvres.2004.12.004

Quintaneiro, C.; Monteiro, M.; Pastorinho, R.; Soares, A.M.V.M.; Nogueira, A.J.A.; Morgado, F.; Guilhermino, L. (2006) - Environmental pollution and natural populations: A biomarkers case study from the Iberian Atlantic coast. Marine Pollution Bulletin, 52(11):14061413. DOI: $10.1016 /$ j.marpolbul.2006.04.002

Ramos, S.; Ré, P.; Bordalo, A.A. (2010) - Recruitment of flatfish species to an estuarine nursery habitat (Lima estuary, NW Iberian Peninsula). Journal of Sea Research, 64(4):473-486. DOI: 10.1016/j.seares.2010.01.010

Sousa, R.; Dias, S.; Antunes, J.C. (2006) - Spatial subtidal macrobenthic distribution in relation to abiotic conditions in the Lima estuary, NW of Portugal. Hydrobiologia, 559(1):135-148. DOI: 10.1007/s10750-005-1371-2

Sousa, R.; Dias, S.C.; Guilhermino, L.; Antunes, C. (2008a) - Minho river tidal freshwater wetlands: Threats to faunal biodiversity. Aquatic Biology, 3(3):237-250. DOI: 10.3354/ab00077

Sousa, R.G.; Dias, S.; Freitas, V.; Antunes, C. (2008b) Subtidal macrozoobenthic assemblages along the River Minho estuarine gradient (north-west Iberian Peninsula). Aquatic Conservation: Marine and Freshwater Ecosystems, 18(7):1063-1077. DOI: $10.1002 /$ aqc. 871

Statsoft (2012) - Electronic statistics textbook. Statsoft inc., Tulsa, OK, U.S.A. Available at http://www.statsoft.com/ textbook/

Teixeira, H.; Salas, F.; Borja, A.; Neto, J.M.; Marques, J.C. (2008) - A benthic perspective in assessing the ecological status of estuaries: The case of the Mondego estuary (Portugal). Ecological Indicators, 8(4):404-416. DOI: 10.1016/j.ecolind.2007.02.008 
Appendix A. List of the identified epibenthic taxa in each sampling station of Cávado Estuary and other small benthic taxa (n.i. - not identified). For each taxa, the abundance (number of individuals) and the biomass (g). For each sampling station, total number of species, Margalef species richness, Pielou's evenness, Shannon-Wiener diversity and Simpson diversity. $\left({ }^{*}\right)$ Gobidae not Pomatoschistus.

\begin{tabular}{|c|c|c|c|c|c|c|c|c|c|c|}
\hline \multirow{2}{*}{ Epibenthic Taxa } & \multicolumn{2}{|c|}{ Station E1 } & \multicolumn{2}{|c|}{ Station E1a } & \multicolumn{2}{|c|}{ Station E2 } & \multicolumn{2}{|c|}{ Station E3 } & \multicolumn{2}{|c|}{ Station E3a } \\
\hline & Abundance & Biomass & Abundance & Biomass & Abundance & Biomass & Abundance & Biomass & Abundance & Biomass \\
\hline \multicolumn{11}{|l|}{ Arthropoda } \\
\hline Neomysis integer (Leach, 1814) & 127 & 2.861 & 18 & 0.230 & 61 & 1.005 & 151 & 2.639 & 39 & 0.607 \\
\hline Siriella armata (Milne-Edwards, 1837) & & & & & & & & & 1 & 0.033 \\
\hline Carcinus maenas (Linnaeus, 1758) & 35 & 128.460 & 66 & 77.434 & 170 & 361.524 & 296 & 631.349 & 103 & 1425.427 \\
\hline Atyaephyra desmarestii (Millet, 1831) & 3 & 0.349 & & & 5 & 0.396 & 5 & 0.389 & & \\
\hline Crangon crangon (Linnaeus, 1758) & 326 & 40.565 & 273 & 20.388 & 1293 & 108.615 & 2930 & 302.204 & 660 & 62.602 \\
\hline Palaemon elegans Rathke, 1837 & 1 & 0.201 & 4 & 0.360 & 10 & 1.710 & & & 22 & 5.392 \\
\hline Palaemon serratus (Pennant, 1777) & 1 & 0.102 & & & 36 & 6.428 & 18 & 1.512 & 56 & 11.689 \\
\hline Palaemonetes varians (Leach, 1813) & 1 & 0.079 & & & & & 2 & 0.142 & 4 & 0.764 \\
\hline \multicolumn{11}{|l|}{ Vertebrata } \\
\hline Anguilla anguilla (Linnaeus, 1758) & 2 & 13.946 & 8 & 2.680 & 6 & 176.290 & 1 & 0.335 & & \\
\hline Gobidae n.i.* & & & & & & & 2 & 0.128 & 0 & \\
\hline Pomatoschistus microps (Krøyer, 1838) & 171 & 52.404 & 34 & 7.539 & 173 & 46.393 & 127 & 45.882 & 48 & 17.802 \\
\hline Pomatoschistus minutus (Pallas, 1770) & 12 & 2.984 & & & 4 & 2.532 & 4 & 1.572 & 3 & 0.564 \\
\hline Platichthys flesus (Linnaeus, 1758) & 7 & 88.180 & 4 & 2.426 & & & 4 & 5.100 & 2 & 0.198 \\
\hline Solea solea (Linnaeus, 1758) & & & & & 1 & 1.030 & 8 & 4.592 & 2 & 0.168 \\
\hline Syngnathus acus Linnaeus, 1758 & 1 & 1.818 & & & 2 & 1.555 & 9 & 11.045 & & \\
\hline Total & 687 & 331.950 & 407 & 111.057 & 1761 & 707.478 & 3557 & 1006.890 & 940 & 1525.246 \\
\hline Total number of species & 12 & & 7 & & 1 & & 13 & & 1 & \\
\hline $\mathrm{d}=$ Margalef species richness & 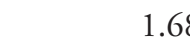 & & 0.9 & & 1.3 & & 1.4( & & 1.4 & \\
\hline $\mathrm{J}^{\prime}=$ Pielou's evenness & 0.5 & & 0.5 & & 0.4 & & 0.27 & & 0.4 & \\
\hline $\mathrm{H}^{\prime}(\log \mathrm{e})=$ Shannon-Wiener diversity & 1.30 & & 1.0 & & 0.9 & & 0.7 & & 1.1 & \\
\hline $1-\lambda^{c}=$ Simpson diversity & 0.6 & & 0.5 & & 0.4 & & 0.3 & & 0.4 & \\
\hline \multirow{2}{*}{ Other small benthic taxa } & \multicolumn{2}{|c|}{ Station 1} & Statio & $1 \mathrm{a}$ & Stati & & Static & & Static & \\
\hline & Abundance & Biomass & Abundance & Biomass & Abundance & Biomass & Abundance & Biomass & Abundance & Biomass \\
\hline Annelida & & & & & & & & & & \\
\hline Polychaeta n.i. & 222 & 0.039 & 8 & 0.002 & & & 234 & 0.085 & 23 & 0.007 \\
\hline Capitella capitata (Fabricius, 1780) & & & & & & & 4 & 0.005 & & \\
\hline Nereidae n.i. & & & 24 & 0.003 & 1 & 0.011 & & & 4 & 0.154 \\
\hline Hediste diversicolor (O.F. Müller, 1776) & 54 & 1.442 & 82 & 0.075 & 8 & 0.019 & 14 & 0.137 & 18 & 1.016 \\
\hline Streblospio benedicti Webster, 1879 & & & 2 & 0.000 & & & 72 & 0.065 & 25 & 0.011 \\
\hline Oligochaeta n.i. & 52 & 0.016 & 18 & 0.008 & & & 24 & 0.014 & 3 & 0.002 \\
\hline Tubificidae n.i. & 25 & 0.040 & & & & & 8 & 0.009 & & \\
\hline Mollusca & & & & & & & & & & \\
\hline Bivalvia & & & & & & & & & & \\
\hline Cerastoderma edule (Linnaeus, 1758) & & & & & & & & & 4 & 5.948 \\
\hline Cerastoderma glaucum (Bruguière, 1789) & 1 & 0.045 & & & & & 8 & 0.876 & 3 & 4.716 \\
\hline Cerastoderma sp. & & & & & & & & & 1 & 0.005 \\
\hline Scrobicularia plana (da Costa, 1778) & & & & & & & 72 & 0.336 & & \\
\hline Mytilus galloprovinciallis Lamarck, 1819 & & & & & & & & & 7 & 321.309 \\
\hline Gastropoda & & & & & & & & & & \\
\hline Peringia ulvae (Pennant, 1777) & 1 & 0.006 & & & & & & & 1 & 0.003 \\
\hline Hydrobia sp. & 12 & 0.045 & & & & & & & & \\
\hline Arthropoda & & & & & & & & & & \\
\hline Crustacea & & & & & & & & & & \\
\hline Isopoda n.i. & 1 & $<0.001$ & & & & & & & & \\
\hline Gnathia sp. & 1 & $<0.001$ & & & & & & & & \\
\hline Cyathura carinata (Kroyer, 1847) & 2 & 0.039 & 2 & 0.000 & 4 & 0.116 & 34 & 0.279 & 22 & 0.207 \\
\hline Sphaeroma serratum (Fabricius, 1787) & 142 & 0.790 & 223 & 1.330 & 34 & 0.381 & 32 & 0.401 & 1 & 0.006 \\
\hline Tanais dulongii (Audouin, 1826) & 32 & 0.005 & 66 & 0.000 & & & 8 & $<0.001$ & 2 & $<0.001$ \\
\hline Heterotanais oerstedii (Kroyer, 1842) & 16 & $<0.001$ & & & 20 & $<0.001$ & & & 2 & $<0.001$ \\
\hline Amphipoda n.i. & 109 & 0.078 & 34 & 0.026 & 40 & 0.032 & 4 & 0.011 & 2 & 0.003 \\
\hline Corophium multisetosum Stock, 1952 & 641 & 0.878 & 46 & 0.086 & 16 & 0.028 & 9 & 0.022 & & \\
\hline Corophium sp. & 187 & 0.100 & & & 4 & 0.012 & 8 & 0.024 & 1 & 0.007 \\
\hline Gammaridae n.i. & 99 & 0.316 & 30 & 0.072 & 24 & 0.137 & & & & \\
\hline Echinogammarus marinus (Leach, 1815) & 290 & 0.995 & 28 & 0.109 & 126 & 0.518 & 11 & 0.045 & 8 & 0.021 \\
\hline Echinogammarus stoerensis (Reid, 1938) & 218 & 1.177 & 14 & 0.042 & 82 & 0.656 & 11 & 0.108 & 6 & 0.216 \\
\hline Leptocheirus pilosus Zaddach, 1844 & 46 & 0.078 & 92 & 0.096 & 532 & 0.657 & 4 & 0.006 & 4 & 0.009 \\
\hline Melita hergensis Reid, 1939 & 57 & 0.263 & 8 & 0.003 & & & 4 & 0.015 & 8 & 0.027 \\
\hline Melita palmata (Montagu, 1804) & 1 & 0.006 & & & 6 & 0.041 & 4 & 0.040 & 10 & 0.110 \\
\hline Hexapoda & & & & & & & & & & \\
\hline Insecta n.i. & 8 & $<0.001$ & & & & & & & 2 & $<0.001$ \\
\hline Chironomidae n.i. & 26 & 0.007 & & & 74 & 0.039 & 11 & 0.019 & 3 & 0.011 \\
\hline Orthocladinae n.i. & 36 & 0.025 & & & 62 & 0.034 & & & 2 & 0.002 \\
\hline Culicinae n.i. & & & & & & & 2 & 0.003 & & \\
\hline Microvelia sp. & 4 & 0.002 & & & & & & & & \\
\hline
\end{tabular}

